УДК 373.21

\title{
ФОРМИРОВАНИЕ СЕМЕЙНЫХ ЦЕННОСТЕЙ В ДОШКОЛЬНЫХ ОБРАЗОВАТЕЛЬНЫХ ПРОГРАММАХ
}

\author{
Селезнёва Екатерина Александровна \\ аспирант 3 курса \\ факультет педагогики и психологии \\ Научный руководитель: Веракса Николай Евгеньевич \\ доктор психологических наук, профессор \\ МПГУ
}

\begin{abstract}
Аннотация: Формирование семейных ценностей и традиций является одной из важнейших задач дошкольного периода. Автором статьи был проведён опрос 100 респондентов с детьми дошкольного возраста по вопросам воспитания у детей семейных ценностей. Представления о семье и семейных ценностей у детей сформированы недостаточно, поэтому важна педагогическая поддержка молодой семьи в вопросах воспитания $\mathrm{y}$ дошкольников семейных ценностей и традиций. В статье автор исследует насколько эффективно в современных дошкольных образовательных программах формируются у дошкольников семейные ценности. Результаты анализа подтверждают гипотезу данной работы о том, что в дошкольных образовательных программах нет полноценных программ по воспитанию семейных ценностей у дошкольников. Решением проблемы автор статьи видит освоение детьми образа семьи и семейных ценностей в процессе совместных проектов семьи и дошкольной образовательной организации.
\end{abstract}

Ключевые слова: семья, семейные ценности, семейные традиции, дошкольники, формирование, дошкольные образовательные программы.

\section{FORMATION OF FAMILY VALUES IN PRESCHOOL EDUCATIONAL PROGRAMS}

\author{
Selezneva Ekaterina Alexandrovna \\ Veraksa Nikolai Evgenyevich
}


Abstract: The formation of family values and traditions is one of the most important tasks of the preschool period. The author of the article conducted a survey of 100 respondents with preschool children on the issues of upbringing family values in children. Children do not have full knowledge about the family and family values. It is very important to support young families by preschool in matters of upbringing family values and traditions in children. In the article, the author examines how effectively are preschool educational programs in formation of family values in preschoolers. The results of the analysis confirm the hypothesis of this work that there are no full-fledged programs for the formation in children of family values in preschool educational programs. As a solution to this problem, the author of the article sees projects activities of the family and the preschool educational organization in the development of family image and family values in children.

Key words: family, family values, family traditions, preschoolers, formation, preschool educational programs.

Проблема воспитания семейных ценностей и традиций у детей является актуальной и определяется той огромной ролью, которая играет семья в социально-нравственном развитии ребёнка. Автор статьи уверен, что воспитывать у дошкольников семейные ценности важно во взаимодействии дошкольной образовательной организации и семьи через проведение мероприятий и семейных проектов.

Действующий ФГОС дошкольного образования декларирует необходимость формирования семейных ценностей у детей дошкольного возраста в рамках освоения социально-коммуникативного направления развития в ДОУ. В пункте 1.6 указана задача «объединение обучения и воспитания в целостный образовательный процесс на основе духовно-нравственных и социокультурных ценностей и принятых в обществе правил и норм поведения в интересах человека, семьи, общества» [1]. В соответствии со стандартом дошкольное образование предполагает приобщение детей к социокультурным нормам, традициям семьи, общества и государства, развитие у них представлений о ценностях нашего народа, об отечественных традициях и праздниках, формирование уважительного отношения и чувства принадлежности к своей семье. Также стандарт устанавливает обязательное взаимодействие дошкольной образовательной организации и родителей для сотрудничества в вопросах воспитания детей, 
проведения совместных проектов и праздников. Всё это обуславливает актуальность изучения программ и методов развития семейных ценностей у дошкольников.

Из этого вытекает направленность на проблему исследования насколько эффективна поддержка семьи ДОУ в вопросах воспитания семейных ценностей у дошкольников? Взаимодействие воспитателей с родителями в данном направлении способствует формированию бережного отношения к семейным ценностям и сохранению семейных традиций.

В связи с происходящими переменами в современном обществе молодые родители уделяют всё меньше времени и внимания воспитанию семейных ценностей и традиций. Индустриализация, индивидуализация, ориентация на личностные успехи, переход на удаленную работу и учёбу, и другие современные тенденции в определенной мере лишили семью воспитательной функции.

Был проведён опрос 100 родителей с детьми дошкольного возраста, а также беседа с детьми про семейные ценности и традиции. Средний возраст респондентов - 32 года, из них 72\% женщин и 28\% мужчин. Респонденты из разных городов России, опрос проводился с помощью социальных сетей. 79\% опрашиваемых имеют 1 ребёнка, 17\% - 2-х детей, 4 \% - 3-х детей. Большинство респондентов ежедневно уделяет время для общения с каждым ребёнком, не менее часа (82\% респондентов), 68\% респондентов привлекают детей к посильной помощи в бытовых домашних вопросах и только 43\% респондентов принимают важные решения совместно с детьми. Следует отметить, что совместная деятельность детей и родителей воспитывает в детях чувство ответственности, способствует сплоченности семьи. Но в последнее время ежедневно уделять детям время может далеко не каждая семья в связи с высоким темпом жизни, большинство родителей проводят время с ребёнком до и после детского сада не более 1-2 часов в день.

Среди семейных ценностей большинство респондентов считает любовь, взаимопонимание и поддержку - неизменные ценности для всех поколений. Семейные традиции, которые придерживаются молодые семьи в России: праздники (Новый год, день рождения, рождество, 8 марта, 23 февраля, пасха и 9 мая), совместный просмотр фильмов и мультфильмов, совместные приёмы пищи, отпуск и организацию досуга на выходных.

Было также опрошено 82 ребёнка данных респондентов в возрасте от 4 до 7 лет, 66\% из которых не смогли дать определение семьи, остальные 
дети семьёй считают группу членов семьи с детьми. Большинство детей (89\%) не знает, что такое семейные ценности и определяют их как богатство семьи, материальные вещи, такие как драгоценности, машины и недвижимость. Совместными занятиями с родителями дети назвали: компьютерные игры, просмотр мультфильмов, прогулки в парке, поход в магазин.

В результате проведенного опроса можно сделать вывод, что сформированность представлений о семейных традициях и ценностях у дошкольников и их родителей очень низкая, отсутствует понимание, что такое «семья», какие существуют ценности и традиции в семье. Многие дети не могут охарактеризовать значимость семьи для человека, а родители недооценивают важность воспитания у ребёнка семейных ценностей, привития интереса к изучению и сохранению семейных обычаев и традиций в семье. Молодым семьям в нашей стране не хватает педагогической поддержки со стороны дошкольных учреждений, где дети проводят большинство своего времени в течение недели.

В связи с вышеперечисленными тенденциями можно отметить, что воспитательная функция в семье ослабла в последнее время, дети стали воспитываться по большей части вне дома - в детских садах, и глубокое влияние на них стали оказывать педагоги и воспитатели, которые работают по установленным в дошкольных образовательных учреждениях программах.

Проведём анализ современных образовательных программ для детских садов по вопросу воспитания семейных ценностей у детей. Автором статьи были проанализированы комплексные и парциальные программы дошкольного образования: «Развитие» (Авторы: Л.А. Венгер, О.М. Дьяченко, Н.С. Варенцова и др.) [2], «Радуга» (Авторы: Т.Н. Доронова, В.В. Гербова, Т.И. Гризик, Е.В. Солошева и др.) [3], «От рождения до школы» (Автор: Н.Е. Веракса, Т.С. Комарова, М.А. Васильева) [4], «Истоки» (Авторы: Л.А. Парамонова, Т.И. Алиева, А.Н. Давидчук и др.) [5], «Детство» (Авторы: В.И. Логинова, Т.И. Бабаева, Н.А. Ноткина и др.) [6], «Открой себя» (Автор: Е.В. Рылеева), «Я - человек» (Автор: С.А. Козлова) [7], «Приобщение детей к истокам русской народной культуры» (Авторы: О.Л. Князева, М.Д. Маханева) [8], «Развитие у детей представлений об истории и культуре» (Авторы: Л.Н. Галигузова, С.Ю. Мещерякова) [9], «Наследие» (Автор: М.Ю. Новицкая) [10], «Непреходящие ценности малой Родины» (Автор: Е.В. Пчелинцева) [11], «Мой родной дом» (Авторы: Э.П. Костина, Н.Н. Кочнева) [12]. 
Во всех рассмотренных программах сделан акцент либо на развитие у ребёнка знаний и представлений о семье, либо на нравственное и ценностно-ориентированное воспитание дошкольников. В программах не охватывается вся совокупность знаний и представлений о семье, семейных ценностях и нравственном отношении. В связи с данной тенденцией, у дошкольников не формируется целостный образ семьи, происходит развитие представлений о семье только с одной стороны.

Анализ программ позволяет сделать выводы, что в большинстве программ («Истоки», «Детство», «Открой себя», «Развитие» и другие) знания о семье предполагают полоролевую направленность, где институт семьи рассматривается как возможность для воплощения социальных ролей. В некоторых программах как «Гармония», «Детство», «Я - человек» акцент делается на социализацию ребенка в процессе взаимодействия с членами семьи и воспитание гуманных чувств по отношению к ним. Большинство программ рассматривает развитие у детей интереса к семье через изучение истории своей семьи, генеалогии, её корней («Открой себя», «Я - человек», «Непреходящие ценности малой Родины», «От рождения до школы», «Приобщение детей к истокам русской народной культуры» и другие). Представления о семье, полученные в результате изучения ее истории и генеалогии, становятся основой для более глубокого осмысления родственных отношений и понятий «семья», «род» «родственники», «родственные связи», «поколение». В процессе изучения ребёнок осознает смысловое значение слова «род», понимает необходимость хранить память о своих родных, об истории своей семьи.

В развивающих программах, целью которых является приобщение к истории и народной культуре («Наследие», «Развитие у детей представлений об истории и культуре», «Непреходящие ценности малой Родины», «Я - человек» «Приобщение детей к истокам русской народной культуры»), прививают детям интерес к народным праздникам, обычаям и традициям. Через изучение народной культуры рассматривается и ценность семейного уклада, её особенности. В таких программах стараются привить детям чувство родства с семьей, побудить их к проявлению отзывчивости на состояние взрослых и уважительного отношения к ним. Вся работа в ДОУ строится по темам: «Моя семья», «Семь Я», «Наши имена и фамилии», «Традиции моей семьи», «История моей семьи», «Моя родословная», «Мой папа - Защитник 
Отечества», «Моя мама - самая лучшая на свете», «Профессии моих родителей».

Согласно программе «От рождения до школы» под редакцией Н.Е. Вераксы, Т.С. Комаровой и М.А. Васильевой, предполагается сформировать у детей интерес к своей семье, ее истории и родословной [4]. $\mathrm{B}$ программе выделяется четыре этапа формирования знаний об истории семьи: обучение педагогов и работа с родителями по составлению родословных, семейные проекты «Моя родословная» или «Дерево моей семьи» и беседы со старшими дошкольниками про семью. Этапы формирования образа семьи и интереса к семье на примере программы «От рождения до школы» описывают предоставление детям знаний только со стороны истории своей семьи и родословной.

Проведенный анализ действующих программ говорит о том, что получение дошкольниками знаний о семье является узконаправленным и зависит от уклона образовательной программы. Программам не хватает целостности в вопросе воспитания семейных ценностей и представлений о семье у дошкольников. Также следует отметить, что программы, в которых есть план по формированию у детей знаний о семье, акцентируют внимание только на информационно-содержательном компоненте, эмоциональная и чувственная составляющая игнорируется. Положительные эмоции ребенка в семье и чувства к членам семьи, по мнению автора данной статьи, является одним из самых важных и определяющих компонентов в формировании представлений о семье у дошкольников. Общими усилиями семьи и детского сада можно повлиять на становление положительного образа семьи у детей дошкольного возраста.

Только взаимодействие семьи и дошкольной образовательной организации может обеспечить сохранение традиций и обычаев, обеспечить передачу потомкам всего положительного, что накапливается семьей. Дошкольная образовательная организация может помочь семье, если создаст условия для эффективного взаимодействия детского сада и семьи по воспитанию $\mathrm{y}$ дошкольников семейных ценностей. Важно привлекать родителей к совместным проектам по ознакомлению с семейными традициями и историей семьи. Задачи дошкольного учреждения состоят в воспитании у детей любви и уважения к родительскому дому, членам семьи, старшему поколению, показать значимость семьи в жизни каждого человека, вызывать интерес к семье и её истории. 
В педагогическом процессе дошкольной образовательной организации важно использовать разнообразные методы и формы работы с детьми и взрослыми, такие как беседы, рассматривание семейных альбомов, картин известных художников, иллюстраций к книгам, организация выставки детских работ, дидактические и сюжетно-ролевые игры, чтения стихов, пословиц и поговорок, сочинение рассказов о семье, проведение семейных конкурсов и праздников, театрализованная и проектная деятельность. Для того чтобы родители осознанно подходили к участию совместных мероприятий важно проводить консультации, создавать визуальную информацию, привлекать родителей к совместным проектам с детьми. Например, делать творческие проекты, составлять рассказы об истории своей семьи, о родном городе, сочинять стихотворения, делать небольшие макеты своего дома, составлять семейные фотоальбомы и т.д. Так хорошим проектом про семейные ценности может быть «Семейная книга», где в наглядной форме родители и дети представят семейные ценности, традиции, увлечения, свою родословную, придумают герб и гимн семьи, осветят достижения членов семьи в различных сферах деятельности и семейные профессии. Такие проекты развивают интерес ребёнка к семье, семейным ценностям и традициям, сплачивают членов семьи, налаживают взаимодействие семьи и дошкольных образовательных учреждений. Проектная деятельность про семейные ценности развивает у дошкольников стремление собрать как можно больше информации о своей семье, желание реализовать знания о прошлом семьи в собственной деятельности (рассказы, рисунки, предъявление семейных реликвий). Проявляется эмоционально-положительное отношение к своей семье, гордость за свою семью, бережное отношение к семейным традициям и ценностям.

В заключение следует отметить, что воспитательная функция семьи ослабла в последнее время из-за происходящих перемен в обществе. В современных молодых семья в нашей стране уделяется мало внимания и времени на изучение и сохранение семейных обычаев и традиций, поддержания интереса ребёнка к своей семье и её ценностям. Сформированность представлений о семейных традициях и ценностях у дошкольников и их родителей очень низкая, отсутствует понимание значимости семьи и какие существуют ценности и традиции в семье. Молодому поколению в нашей стране нужна поддержка со стороны 
дошкольных учреждений в вопросах воспитания и развития семейных ценностей у детей.

Одной из основных проблем освоения детьми представлений о семье в ДОУ является нецелостный образ семьи, а также односторонние знания, в зависимости от уклона программы. Анализ программ дошкольного образования позволяет сделать вывод, что поддержка семьи дошкольными образовательными организациями неэффективна. Развитие представлений о семье в ДОУ является неполноценным и узконаправленным, носит информационный характер и затрагивает только вопросы о членах семьи и её генеалогии. Уделяется мало внимания воспитанию семейных ценностей, эмоционального отклика и интереса у детей про историю и особенности своей семьи, про семейные профессии и достижения, реликвии и традиции.

Автор статьи уверен, что решением данной проблемы является составление комплексной и полноценной программы по воспитанию семейных ценностей у дошкольников, которая будет включать проектную деятельность, направленную на формирование целостного образа у дошкольников о семье и её ценностях, привлекая родителей к совместной деятельности с детьми. Целенаправленное воспитание семейных ценностей и представлений о семье у дошкольников сегодня способно в будущем укрепить институт семьи в нашей стране.

\section{Список литературы}

1. ФГОС ДО от 17.10.2013 N 1155 (ред. от 21.01.2019). [Электронный pecypc] URL: https://fgos.ru/fgos/fgos-do/ (дата посещения: 12.12.2021).

2. Примерная основная общеобразовательная программа дошкольного образования «Развитие». Программно-методическое пособие. Проект. Москва, Издательство: НОУ «УЦ им. Л.А. Венгера «Развитие», 2012. - 144 с.

3. Примерная основная общеобразовательная программа дошкольного образования «Радуга», Москва, Издательство: «Просвещение», 2014. - 232 с.

4. Примерная основная общеобразовательная программа дошкольного образования «От рождения до школы» / Под ред. Н.Е. Вераксы, Т.С. Комаровой, М.А. Васильевой. - М.: МОЗАИКА СИНТЕЗ, 2014. - 368 с.

5. Примерная образовательная программа дошкольного образования «Истоки». - 5-е изд. -М.: ТЦ Сфера, 2014. - 161 с. 
6. Примерная образовательная программа дошкольного образования «Детство» / Т.И. Бабаева, А.Г. Гогоберидзе, О.В. Солнцева и др. - СПб.: ООО «Издательство: «Детство» ПРЕСС», 2014. - 280 с.

7. Примерная образовательная программа дошкольного образования «Открой себя» Е.В. Рылеева. - Издательство: Линка-Пресс, 2009. - 164 с.

8. Примерная образовательная программа дошкольного образования «Приобщение детей к истокам русской народной культуры» О.Л. Князева, М.Д. Маханева, [Электронный ресурс] URL: http://dou-17.unosmirnih.ru/files/ obr_prog/obr_pr_knyzeva.pdf (дата посещения: 11.02.2021).

9. Примерная образовательная программа дошкольного образования «Развитие у детей представлений об истории и культур» / программа Л.Н. Галигузова, С.Ю. Мещерякова. - М.: Академия, 2011.

10. Примерная образовательная программа дошкольного образования «Наследие: программа нравственно-патриотического воспитания» Новицкая М.М., Соловьева Е.В. / - М.: Академия, 2013.

11. Программа дошкольного образования «Непреходящие ценности малой Родины» / Пчелинцева Е.В. Методические рекомендации. - г. Иваново АУ «Институт развития образования Ивановской области», 2009.

12. Программа дошкольного образования «Мой родной дом. Программа нравственно-патриотического воспитания дошкольников». Под общ. ред. Т.И. Оверчук. Издательство: Мозаика-Синтез, Москва, 2004. 